
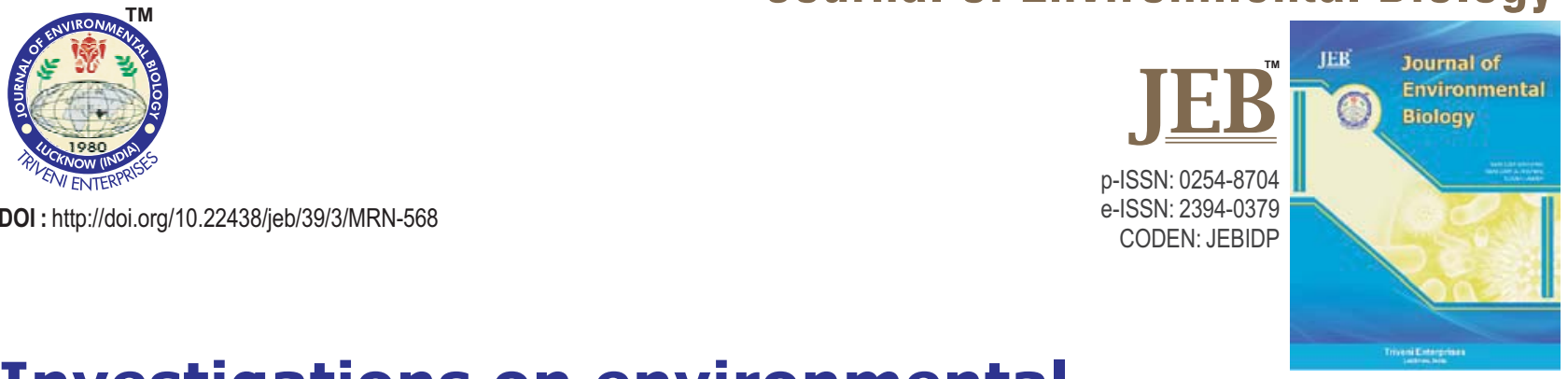

\title{
Investigations on environmental emissions characteristics of CI engine fuelled with castor biodiesel blends
}

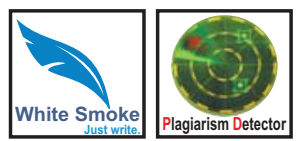

Authors Info

S.K. Mahla ${ }^{1 *}$ A. Dhir ${ }^{2}$, V. Singla and P. Rosha ${ }^{2}$

${ }^{1}$ Department of Mechanical Engineering, I.K. Gujral Punjab Technical University Campus, Hoshiarpur-146 001, India

${ }^{2}$ School of Energy and Environment, Thapar University, Patiala-147 004, India

*Corresponding Author Email : mahla.sunil@gmail.com

Key words

Biodiesel

Brake thermal efficiency

Exhaust emissions

Ricinus communis

Transesterification

\section{Publication Info}

Paper received : 20.01 .2017

Revised received : 18.05.2017

Re-revised received : 08.08.2017

Accepted: 13.10 .2017

\section{Abstract}

Aim : Biodiesel is an attractive fuel option for diesel engines in view of issues related to fossil fuel crisis and environmental degradation. The present study aimed to prepare biodiesel from non-edible grade castor Ricinus communis oil and to evaluate the emission characteristics of castor biodiesel fuelled diesel engine at different engine operating loads.

Methodology : The biodiesel was prepared from non-edible grade castor oil by single step alkaline transesterification process at room temperature.The fuel properties like kinematic viscosity, density, calorific value, flash point, pour point, and cloud point were measured as per ASTM D-6751 specifications. The engine used for experimental work is a single cylinder, four stroke, constant speed, direct injection diesel engine. The engine testing was performed at different engine loads $(0.9,1.8$ and 2.7 bmep) and at constant speed of $1500 \mathrm{rpm}$ with different tested fuel blends i.e. B0, B20, B40 and B60. The emission parameters like nitrogen oxides, hydrocarbons and carbon monoxide were evaluated using flue gas analyzer.

Results : Production yield of $96.5 \%$ was obtained using biodiesel synthesis and castor oil based biodiesel was found to possess similar fuel properties when compared to fossil petro-diesel. At full engine load condition of 2.7 bmep, the hydrocarbon emission was lowered by $24.6,39.6$ and $42.1 \%$ for B20, B40 and $\mathrm{B} 60$ fuels, respectively, and the carbon monoxide emission was reduced by $12.9,17.1$ and $26.2 \%$ for tested fuel blends B20, B40 and B60, respectively, when compared to petro-diesel. At 2.7 bmep load condition, the $\mathrm{NO}_{\mathrm{x}}$ emissions was higher by $28.2 \%$ for $\mathrm{B} 60$ fuel when compared to petro-diesel, while, at 0.9 bmep load condition, $\mathrm{NO}_{\mathrm{x}}$ emissions increased by 11.8 and $15.1 \%$ for $\mathrm{B} 20$ and $\mathrm{B} 40$ blends, respectively, when compared with petro-diesel.

Interpretation: The non-edible grade of castor oil can be used as a raw material for biodiesel production and its blend with diesel is a suitable fuel candidate for use in diesel engine without modifications, which results in overall low emissions.

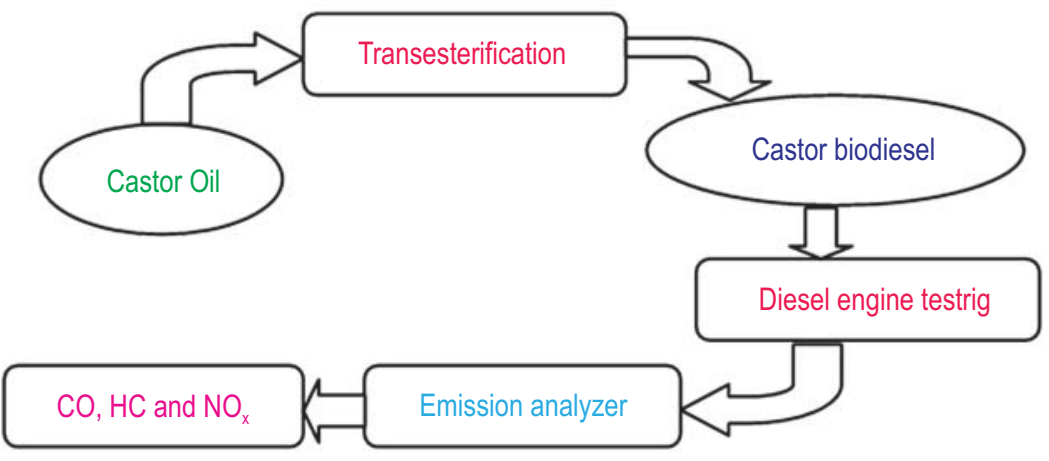




\section{Introduction}

Increasing uncertainty about global energy production and environmental pollution concerns promote stimulus to explore renewable alternative fuels for $\mathrm{IC}$ engines, which would have lesser detrimental influence on the environment. Although some significant step to improve ambient air quality have been taken by regulatory agencies but the situation is alarming in certain cases, which results in serious health implications (Monterio et al., 2009; Gui et al., 2008). Because of nonrenewable nature of fossil fuels and deteriorating air quality, entire world is looking foralternative non-edible oils as a substitute for diesel. Biodiesel has many environmentally beneficial properties. Biodiesel combustion decreases emission of carbon monoxide and unburnt hydrocarbons (Pasupathy Raju et al., 2016). Biodiesel has gained attention as an alternative fuel because of its non-toxic, biodegradable and renewable characteristics. Furthermore, cold flow properties, NOx emissions and high costs are certain considerations that have to be vanquished (Young, 2011; Duraisamy et al., 2010). In the last few decades, there have been major thrust for use of these alternative environmental friendly fuels for transportation purpose (Ogunniyi, 2006). Although, several research studies have been carried out by using different non-edible sources like Mahua oil, Pongamia oil, Neem oil, Jatropha oil etc., and investigated their effect on engine performance and emission (Scholz et al., 2008).

Castor oil, extracted from seeds of Ricinus communis, belongs to the family of Euphorbiaceae, can be used as biodiesel feed stock. World's average total production of castor seed has been reported to be around 12.5 lakh tons and is available in more than 30 countries. India ranks among one of the top producers of castor and its derivatives contribute to almost $65 \%$ share (Deep et al., 2017). Different varieties of castor seeds generally contain on an average of about $46-55 \%$ oil by weight (Gunstone, 2004). Due to the presence of ricin, ricine and certain allergens, castor seeds are poisonous to humans and animals (Nangbes et al., 2013). It is hard non-drying, viscous, pale yellow and non-volatile oil (Aydin et al., 2010). Paradox to other vegetable oils, it is characterized for its indigestibility, high hygroscopicity, high viscosity $\left(226 \mathrm{~m}^{-2} \mathrm{~s}\right.$ at $\left.40^{\circ} \mathrm{C}\right)$ and partial solubility in alcohol. These properties increase the viability of this oil for the industrial production of coating, plastic and cosmetics, but limitits application as a biofuel (Hasimoglu et al., 2008).

Literature study indicates limited work on the fuel characterization of castor oil based biodiesel and its utilization with emphasis on environmental implications. Keeping in view of this, utilization of castor oil for biodiesel production and its impact on emission characteristics in a light duty unmodified diesel engine was assessed. The engine behavior with respect to emission characteristics is compared against a fossil petrodiesel. The present study was carried out to evaluate the suitability of higher percentage blend of castor oil based biodiesel-diesel blends on the emission characteristics at different engine loads in order to create a self-sustained source of energy in India.

\section{Materials and Methods}

Biodiesel preparation process : Free fatty acid can cause saponification instead of biodiesel production, so it is important to know the free fatty acid content of oil. The free fatty acid of castor oil was found to be less than $1 \%$ (Table 1). Single step alkaline based trans-esterification process was employed for preparation of biodiesel from castor oil. The process of optimization was done on the basis of oil to methanol molar ratio, amount of catalyst, reaction temperature and residence time of reaction. As these variables has great influence on the yield of ester produced. The biodiesel reactor unit consists of glass flask, heating oil bath, reflux condenser, stirrer motor mechanism and temperature indicator. Under optimized conditions, a mixture of $130 \mathrm{ml}$ methanol and $2.5 \mathrm{~g}$ of $\mathrm{NaOH}$ was prepared separately. This mixture was then added to $500 \mathrm{ml}$ of castor oil at ambient temperature and quickly stirred for 1 $\mathrm{hr}$ without heating. The final product was kept overnight in a separating funnel until two layers were formed, the lower layer of glycerol was removed. After washing with distilled water for 3-4 times, crude biodiesel was stirred and heated at $90^{\circ} \mathrm{C}$ to remove moisture traces. After cooling, a light yellow crystal clear biodiesel was formed. The biodiesel yield of $96.5 \%$ was obtained under these optimized conditions at room temperature. The test fuel properties were determined in strict compliance with ASTM norms. The various properties of castor oil based biodiesel and diesel fuel are shown in Table 2.

Experimental setup and test procedure : The engine used for the study is a single cylinder, four stroke, water cooled naturally aspirated, constant speed diesel engine. It is a small utility diesel engine used in various commercial applications. The test bench comprises of diesel engine coupled to an eddy current dynamometer for measuring the power output of the engine (Fig. 1). The various fuel blends used in the study were $B 20, B 40$ and B60 containing $20 \%, 40 \%$ and $60 \%$ biodiesel, respectively. The engine tests were performed at three different engine loads $(0.9$, 1.8 and 2.7 bmep). All the experiments were carried out at constant speed of $1500 \mathrm{rpm}$. The emission parameters studied were carbon monoxide, unburned hydrocarbon and oxides of nitrogen $\left(\mathrm{NO}_{\mathrm{x}}\right)$. The un-burnt hydrocarbon $(\mathrm{UHC})$ and carbon

Table 1 : Fatty acid profile of castor oil

\begin{tabular}{lll}
\hline Fatty acid & Structure & wt \% age \\
\hline Ricinoleic acid & $18: 1$ & 83.97 \\
Palmitic & $16: 0$ & 0.46 \\
Stearic & $18: 0$ & 0.52 \\
Oleic & $18: 1$ & 2.28 \\
Linoleic & $18: 2$ & 0.61 \\
Linolenic & $18: 3$ & 0.33 \\
Dihydroxylstearic & $18: 0$ & 0.24 \\
\hline
\end{tabular}


monoxide (CO) emissions were measured using HG-540 emission gas analyzer and oxides of nitrogen $\left(\mathrm{NO}_{\mathrm{x}}\right)$ by $\mathrm{KM} 19106$ flue gas analyzer. The castor oil based biodiesel was mixed withdiesel (diesel fuel was procured from the local retail outlet of Indian Oil Cooperation Limited) on the volume basis by simple mixing. To ensure higher level of accuracy, all the experiment performed were replicated thrice to get an average value.

\section{Results and Discussion}

Emission of nitrogen oxides $\left(\mathrm{NO}_{\mathrm{x}}\right)$ is one of the toxic air pollutants and the foremost anthropogenic source of its formation is combustion. In the ambient air, automobile and other combustion generated sources account for more than $50 \%$ of $\mathrm{NO}_{x}$ emission emitted. $\mathrm{NO}_{x}$ is generally formed due to dissociation reaction of nitrogen and oxygen inside the combustion chamber during peak combustion process. Since it is a high temperature species, therefore, its formation is influenced by high combustion flame temperature, availability of oxygen and available time for combustion (Monyem et al., 2001). Fig. 2 (a) shows variations in the $\mathrm{NO}_{\mathrm{x}}$ emissions for $\mathrm{B} 0, \mathrm{~B} 20, \mathrm{~B} 40$ and $\mathrm{B} 60$ at different load condition. It is known that formation of $\mathrm{NO}_{x}$ is dependent upon residence time, and peak combustion temperature. At all load conditions, the $\mathrm{NO}_{x}$ emissions were found to increase by increasing the load for different blends. Moreover, the increase in emission of $\mathrm{NO}_{x}$ was proportional to the biodiesel concentration in fuel blend. At 2.7 bmep load condition, the $\mathrm{NO}_{x}$ emission was higher by $28.2 \%$ for $\mathrm{B} 60$ fuel when compared to petro-diesel, while at 0.9 bmep load condition $\mathrm{NO}_{x}$ emissions increased by 11.8 and $15.1 \%$ for B20 and B40 blends, respectively when compared to petro-diesel. It reveals that production of $\mathrm{NO}_{\mathrm{x}}$ emissions was higher for biodiesel blends, because inherent oxygen molecules in biodiesel fuel may provide additional amount of oxygen that causes complete combustion, resulting in high combustion temperature (Jindal et al., 2015). Moreover, higher density and viscosity of biodiesel blends may lead to advancement in injection of fuel, resulting in its early combustion and higher $\mathrm{NO}_{x}$ emissions (Singh etal., 2015).

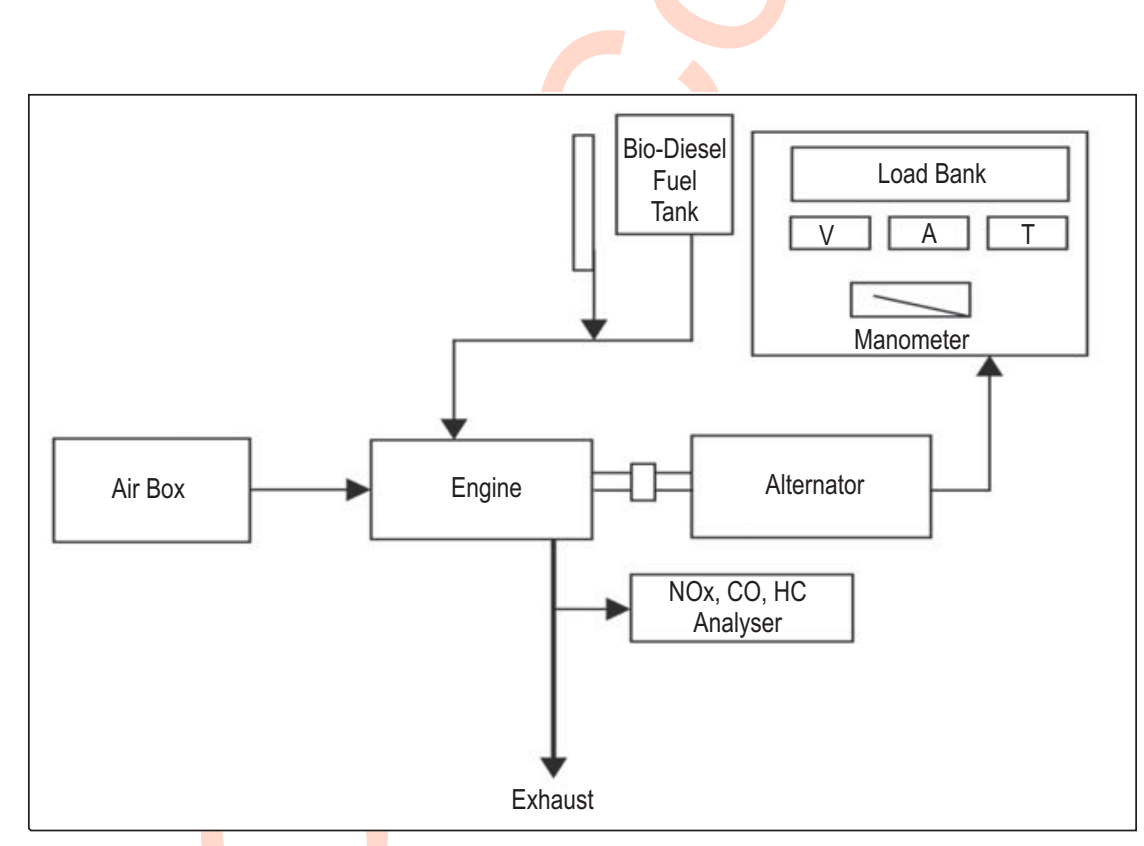

Fig. 1 : Layout of engine test rig used in experimental work

Table 2 : Physical properties of test fuel as per ASTM standard (2008)

\begin{tabular}{|c|c|c|c|c|c|c|}
\hline Property & ASTM standard & ASTM limits & B0 & $\mathrm{B} 20$ & B40 & $\mathrm{B} 60$ \\
\hline $\begin{array}{l}\text { Kinematic viscosity at } \\
40^{\circ} \mathrm{C}(\mathrm{cSt})\end{array}$ & D445 & $1.9-6$ & 2.7 & 3.65 & 4.58 & 5.51 \\
\hline $\begin{array}{l}\text { Density at } 15^{\circ} \mathrm{C} \\
\left(\mathrm{kg} \mathrm{m}^{-3}\right)\end{array}$ & D1298 & 900 & 830 & 844 & 858 & 872 \\
\hline Calorific value $\left(\mathrm{MJkg}^{-1}\right)$ & $\mathrm{D} 240$ & $>33.00$ & 43.4 & 42.7 & 42.0 & 41.3 \\
\hline Flash point $\left({ }^{\circ} \mathrm{C}\right)$ & D93 & $>130$ & 58 & 78 & 108 & 132 \\
\hline Pour point $\left({ }^{\circ} \mathrm{C}\right)$ & D97 & -15 to 10 & -6 & -1 & 4 & 8 \\
\hline Cloud point $\left({ }^{\circ} \mathrm{C}\right)$ & D97 & -2 to -12 & -8 & -5 & -2 & 1.8 \\
\hline
\end{tabular}



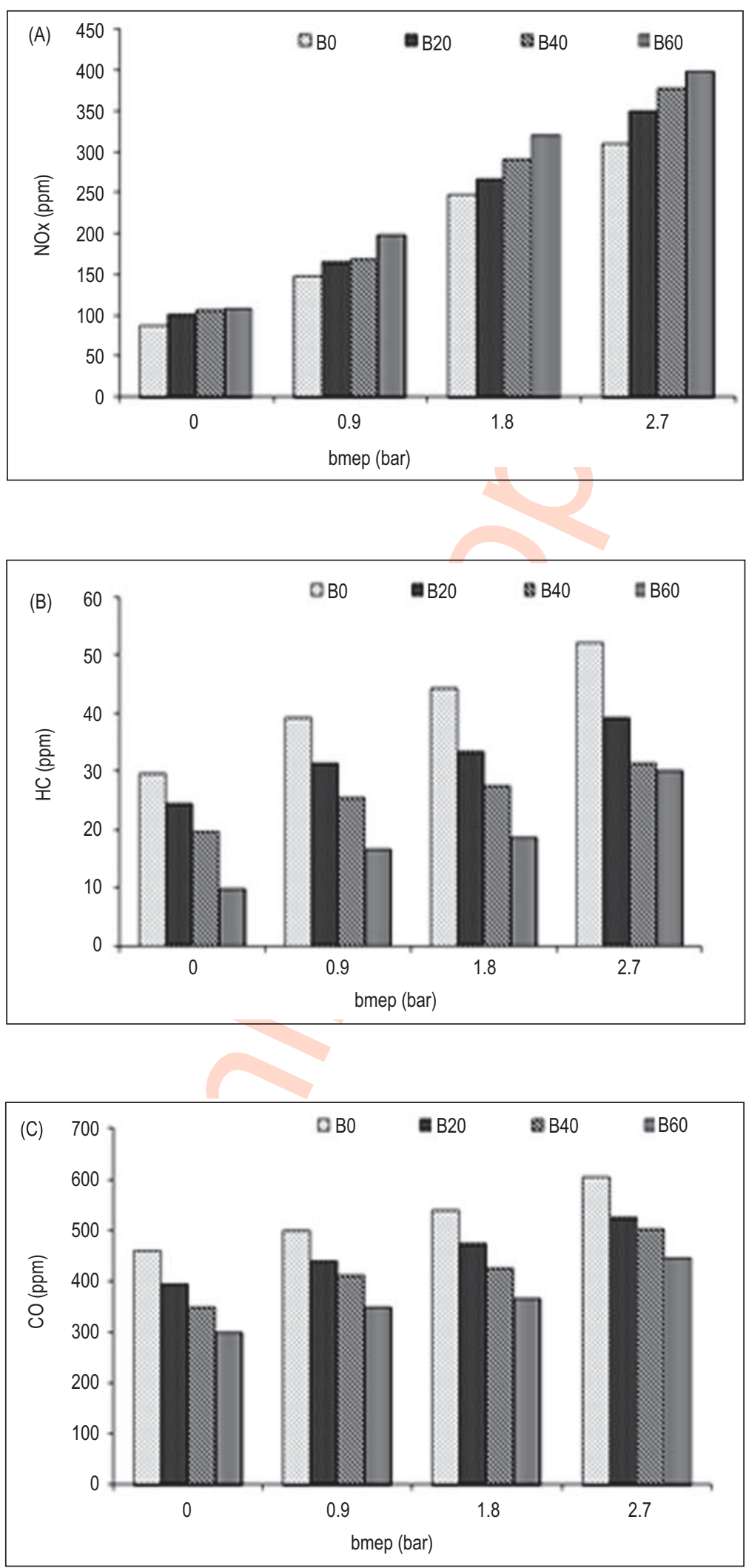

Fig. 2 : Variation in the values of (a) NOx, (b) HC and (c) CO with brake mean effective pressure (bmep) 
On the other hand, Fig. 2(b) shows un-burnt $\mathrm{HC}$ emission traces for pure diesel and different biodiesel blends with conventional diesel. At full engine load condition of $2.7 \mathrm{bmep}$, the hydrocarbon emission was lowered by $24.6,39.6$ and $42.1 \%$ for $\mathrm{B} 20, \mathrm{~B} 40$ and B60 fuels, respectively, when compared to petrodiesel. Thus, at all load conditions, $\mathrm{HC}$ emissions decreased with increasing proportion of biodiesel in the blends which may be attributed to the fact that oxygenated fuels improve the fuel oxidation process and reduces the tendency of unburned $\mathrm{HC}$ emission in exhaust tailpipe. These results are in close agreement with the previous findings, wherein $\mathrm{HC}$ emission reductions were higher with increasing biodiesel concentration (Qi et al., 2010; Sahoo et al., 2009). Moreover, high cetane number of biodiesel blends reduces the ignition delay period which is also responsible for reduction of HC emissions (E-Xue et al., 2011).

The formation of $\mathrm{CO}$ emission depends on the availability of oxygen, carbon content of fuel and combustion efficiency of the participating fuel (Karthikeyan et al., 2016). Variation in CO concentration with bmep for various tested fuels is plotted in Fig. 2 (c) The $\mathrm{CO}$ formation decreased with increase in biodiesel blend, however, $\mathrm{CO}$ emission increased with increase in load for all tested fuels. Moreover, at full engine load of $2.7 \mathrm{bmep}$, the carbon monoxide emission was reduced by $12.9,17.1$ and $26.2 \%$ for tested fuel blends B20, B40 and B60, respectively, when compared to B0 which may be attributed to the enhanced oxidation process favored by higher oxygen content in fuel molecules. In addition, high cetane number of biodiesel concentration improves combustion quality and decreases delay period of fuel, resulting in lower possibility of formation of rich fuel zone that subsequently reduces $\mathrm{CO}$ emissions (Ramesha etal., 2015).

It has been concluded that the fuel properties of biodiesel blends were closer to mineral diesel and are in strict compliance with ASTM D6751 specifications. There was a substantial reduction in $\mathrm{HC}$ and $\mathrm{CO}$ emissions at all engine loads with biodiesel blends when compared to neat diesel fuel. However, biodiesel blends resulted in higher Nox emissions when compared to diesel at all operating loads. Thus, castor biodiesel is a suitable fuel blend to be used in $\mathrm{Cl}$ engines for reducing emissions and abatement of air pollution at source.

\section{Acknowledgments}

The experimentation set up with instrumentation was provided by School of Energy and Environment, Thapar University Patiala. We express our sincere thanks and gratitude to the staff of School of Energy and Environment, Thapar University Patiala for their infrastructural and technical support.

\section{References}

Aydin, H. and H. Bayindir: Performance and emission analysis of cotton seed oil methyl ester in a diesel engine. Renew. Energ., 35, 588-92 (2010).
Deep, A., S.S. Sandhu and S. Chander : Optimization of reaction parameters of transesterification of castor oil. JSIR, 76, 115-118 (2017).

Duraisamy, M.K., T. Balusamy and T. Senthilkumar: Experimental investigation on a mixed biodiesel fueled direct injection diesel engine. IJAER, 5, 253-260 (2010).

E-Xue, J., T.E. Grift and A.C. Hansen: Effect of biodiesel on engine performances and emissions. Renew. Sustain. Energ. Reviews, 15, 1098-1116 (2011).

Gui, M.M., K.T. Lee and S. Bhatia: Feasibility of edible oil vs. non-edible oil vs. waste edible oil as biodiesel feedstock. Energy, 33, 1646-53 (2008).

Gunstone, F.D. : The chemistry of oil and fats. $1^{\text {st }}$ Edn., New York, Blackwell (2004).

Hasimoglu, C., M. Ciniviz, O. Ibrahim, O. Zsert, Y. Icingur, A. Parlak and M.S. Salman: Performance characteristics of a low heat rejection diesel engine operating with biodiesel. Renew. Energ., 33, 17091715 (2008).

Jindal, M., P. Rosha, S.K. Mahla and A. Dhir: Experimental investigation on performance and emissions characteristics of waste cooking oil biodiesel and $n$-butanol blends in a compression ignition engine. RSCAdvan., 5, 33863-68 (2015).

Karthikayen, S. and A. Prathima: Environmental effect of $\mathrm{CeO}_{2}$ nanoadditive on biodiesel. Energy Sources, PartA : Recovery, Uti. Environ. Effe., 38, 3673-3679 (2016).

Monterio, M., A.R.P. Ambrozin, L.M. Liao and A.G. Ferreira: Determination of biodiesel blend levels in different diesel samples by ${ }^{1}$ H NMR. Fuel, 88, 691-696 (2009).

Monyem, A., J.H. Van and J.H.Gerpen: The effect of timing and oxidation on emissions from biodiesel-fueled engines. Transaction of ASAE, 44, 35-42 (2001).

Nangbes, J.G., J.B. Nvau, W.M. Buba and A.N. Zukdimma: Extraction and characterization of castor (Ricinus communis) seed oil. Int. J. Engg. Sci. Technol., 2, 105-109 (2013).

Ogunniyi, D.S.: Castor oil: A vital industrial raw material. Biores. Technol., 97, 1086-1091 (2006).

Pasupathy Raju, S., S. Somasundaram and T. M. Raj : Effect of turbocharger on C.I engine performance and emissions using biodiesel blend. J. Environ. Biol., 37, 1437-1441 (2016).

Qi, D., H. Chen, L.M. Geng and Y.Z.H. Bian : Experimental studies on the combustion characteristics and performance of a direct injection engine fueled with biodiesel/diesel blends. Ene. Conver. Mange., 51, 2985-92 (2010).

Ramesha, D.K., A.S. Bangari, C.P. Rathod and S.R. Chaitanya: Experimental investigation of biogas-biodiesel dual fuel combustion in a diesel engine. Biofuels, 6, 9-19 (2015).

Sahoo, P.K. and L.M. Das: Combustion analysis of Jatropha, Karanja and Polanga based biodiesel as fuel in a diesel engine. Fuel, 88, 994-999 (2009).

Scholz, V. and J.N.D. Silva: Prospects and risks of the use of castor oil as a fuel. Biomass and Bioenergy, 32, 95-100 (2008).

Singh, M. and S.S Sandhu : Performance and emission characteristics of an indirect injection (IDI) multi-cylinder compression ignition (CI) engine using diesel / Argemone maxicana biodiesel blends. RSC Advan., 5, 91069-91081(2015).

Young, S. : Inedible vegetable oils and their derivatives for alternative diesel fuels in $\mathrm{Cl}$ engines : A review. Renew. Sustain. Energ. Revi., 15, 131-149 (2011). 